\title{
PROBLEMS OF IMPORT SUBSTITUTION IN UKRAINE
}

\author{
Myroslava Tsap \\ $\mathrm{PhD}$, Uzhhorod National University, Ukraine \\ Mykola Palinchak \\ Prof. DSc, Uzhhorod National University, \\ e-mail: palinchak_mm@gmail.com, orcid.org/0000-0002-9990-5314, Ukraine \\ Ján Holonič \\ $\mathrm{PhD}$, Comenius University, \\ e-mail: jan@holonic.sk, orcid.org/0000-0003-2165-0275, Slovakia
}

\begin{abstract}
The article analyses the problems of import substitution in Ukraine and features of import substitution policy. Mechanisms of import substitution policy in Ukraine and the concept of "import substitution" are analysed.

The results of import substitution policies are changes in the volume and share of goods produced on the territory of the country, in total domestic consumption, capital and finance, labour and intellectual capital, technologies and know-how, elements of material and technical base, innovative resources, elements of the institutional environment.

Regarding the economic stimulation of import substitution, it should be added that in our country there are practically no economic incentives for the retail network and for the population to be aimed at refusing to purchase imported goods.
\end{abstract}

Keywords: import substitution, Ukraine, economy, politics, industry.

DOI: http://dx.doi.org/10.23856/3702

\section{Introduction}

The problem of the need to ensure import substitution through the development of domestic production is quite comprehensively raised in the State Program for the Development of Domestic Production (Decree of Cabinet of Ministers of Ukraine "On approval of the State Program for the Development of Domestic Production", 12.09.2011, No. 1130). However, import substitution is not considered as a primary objective and expected consequence of the implementation of the set of measures in this programmatic document. On the one hand, we can really agree that with the development of domestic production and the change of positions of its subjects from the domestic market, a significant part of imported goods and services will be displaced. However, the development of domestic production is only a separate and, though important, but not the only direction of the structural policy of import substitution.

Therefore, the provisions of this programmatic document are unable to cover a sufficient set of import substitution measures. Therefore, we question the systematic nature of the provisions of the Program and, accordingly, the lack of expected results. It was planned that the implementation of the Program's activities will reduce the dependence of Ukraine and the annual growth rate of imports of goods to 9-9.5\% in 2013-2015; achieving an average annual growth rate of exports of at least 7-10\%; improvement of the foreign trade balance of goods and services in 2015 at the level of US \$ 1.5-2.0 billion. Obviously, these results have not yet been achieved. 
Although in general, it should be acknowledged that in terms of promoting domestic production, this approach to public policy planning is quite commendable. After all, the areas under which the Program's action plan is developed cover institutional and structural transformations in the fields of science and technology, innovation, structural and technical re-equipping of the real sector of the national economy, implementation of a resource-saving and energy-efficient model of development, enhancement of export and development of the human potential, to prevent unfair competition from imported goods. That is, they are structurally and functionally balanced and, in our opinion, these areas should be taken into account when developing and implementing legal acts on the regulation of import substitution in Ukraine.

However, please note that, for example, the direction of Institutional and structural transformation in the field of science and technology, innovation involves activities aimed at creating industrial clusters, techno parks, industrial parks, innovative internet portals, etc., but does not contain specific tools to bring industry actors closer to education, science, innovation businesses to plan, create and commercialize new, more competitive goods and services. In addition, the measures in this area are not focused on structural changes, such as reducing the share of raw materials, with a low level of innovation, the level of resource and energy consumption, improving investment and financial resources, structural relations between the development of the internal market and the consumer sector.

Another area - "Improving the structure of industrial production and its technological restructuring" - involves a number of relevant and necessary measures of public policy, in particular - to support consumer demand for domestic products, improve the structure of exports and increase the volume of products with high added value, the development of priority economic activities, implementation of energy-saving model of domestic production development, providing innovative and technological modernization of traditional industries, incentivization of SME entities that use new technologies, restructuring of industries with poor competitive performance and others.

However, in view of achieving the goals of import substitution, it was advisable to harmonize the measures of development of the production sector of the state with the state policy of promoting its products to the markets. It is about the development of intermediary institutions that support or directly promote goods to the consumer, provide economic and organizational incentives for the intermediary to sell domestic goods, a large-scale information campaign for the population to promote goods manufactured in our country.

The measures provided for by the State Program for the Development of Domestic Production are imperfect in the context of regulatory regulation of the problem of import substitution. So, task \# 20 - "Creating Organizational and Technical Conditions for Import Substitution" - has the expected result of "... ensuring the development of industries by introducing new technologies (developments) into production, which, in our view, is not identical with the displacement of imported goods and services from the domestic consumer market.. Therefore, the means provided to accomplish this task seem too specific and highly specialized. This is the beginning of production or development of technologies for the manufacture of individual groups of goods and types of products. At the same time, the legislators omitted a large number of other goods, whose sales share in the market is much higher and the production potential of which is available in Ukraine. In our opinion, the measures of the analysed direction should include the formation of organizational structure and management system for managing import substitution processes, development of 
infrastructure to support domestic production and displacement of imported goods, simplification of technical conditions for production and sale of goods for local producers, etc.

In turn, we believe that the problem of import substitution is complex and requires strategic approaches to solve it. It also requires the use of sometimes different tools and means, depending on changes in the market situation at one or another stage of structural changes, institutional reforms, percentages of sales of domestic and import goods. That is the reason for the need to adopt the Law of Ukraine "On State Regulation of Import Substitution", and it is advisable to develop appropriate state, regional and local import substitution programs to implement its provisions and specify the measures of state policy.

This would clearly and correctly define the relevant terms and concepts, goals and objectives of public policy, a set of principles, subjects and objects of regulation. After all, for example, the draft State Target Program on import substitution states that "... import substitution is a process of development and production of products in Ukraine, similar to that supplied from abroad." In our opinion, this definition is imperfect, since, firstly, it is impossible to establish the production of all goods coming from outside and not needed in the country; secondly, the development and start-up of production is not enough, it still needs to be implemented in the domestic or foreign markets, so the object of the problem must be wider - substitution (including production, promotion, sales and consumption) of imported goods by domestic ones; thirdly, in order for the import substitution process to be effective, it should not only concern the substitution of imported goods for sale on the domestic market, but also aim at strengthening the position on the market of domestic producers and enterprises selling goods made in Ukraine, formation of appropriate market infrastructure, productive forces, resource and marketing support, mechanisms and tools for counteracting the growth of import dependency.

The interpretation of the concept of domestic products as manufactured by a resident of Ukraine on its territory and in which the cost of domestic components makes at least $50 \%$ of the cost should be somewhat doubtful. For example, what is negative about the sale in the domestic market of goods manufactured by a domestic enterprise, but not in the territory of Ukraine, or if the cost of domestic components is less than $50 \%$, but the added value (due to the "labor" factor) is significant?

It should be added that the instruments of regulation of import substitution in the draft law are debatable and do not fully reveal the whole arsenal of measures of the state. This is a simplification of permitting procedures for the domestic production, the provision of benefits for VAT and income tax, preferences for public procurement. However, we believe that introduction of international standards of quality, safety management, environmental management of products at domestic enterprises can be as effective as possible, which will help to improve the quality, safety and competitiveness of products of domestic production; development of offset activity for setting up of own production of analogues of production of industrial purpose with attraction of experience and investments of foreign partners; providing financial support to economic entities implementing import substitution projects.

It should be noted that in Ukraine the institutional basis of state regulation of import substitution is not sufficiently formed not only at the central level of government, but it is not built in the vertical of power. To a greater or lesser extent, in most regions of our country, the need to take measures aimed at strengthening the position of local producers and displacing imported goods from the domestic market is not always recognized. But the number of practices for the development and implementation of specialized production in the replacement of state regional programs and projects is extremely limited (Measures are being 
taken in the Luhansk region to implement the program of import substitution of products, 2019).

Please note that domestic realities sometimes create indirect obstacles to the effective management of regional import substitution policies. The point is that local market producers compete not only with imported products, but also with goods shipped from other regions of the country. In this aspect, there are a number of problems of harmonization of the product offer within the framework of interregional, cross-sectoral and intersectoral cooperation, as well as methodological gap in the definition of domestic imports, since there are no detailed statistics on goods imported into the country from other regions. This is also a significant drawback of the organizational and economic mechanism of the state structural policy of regulating import substitution in Ukraine, the elimination of which requires improvement of the institutional and methodological direction of this mechanism, in particular, in our opinion, it is advisable to develop and disseminate methodological recommendations on regional planning and regional planning among local and regional authorities. import substitution policy, the basis of which is the statistical observation and systematization of information by product groups, dividing the foreign and interregional imports, as well as product groups by industry, agriculture, utilities and consumer goods.

The lack of reliable and complete information also impedes market research and the demand for regional industrial and other products, the formation and implementation of largescale marketing programs to support local goods.

It should be added that regional and local government bodies are not sufficiently engaged in organizing and expanding the cooperation of subjects of the real sector of economy, investment companies and innovation firms, creation of regional investment centres and development to form the investment and innovation potential of import substitution policy.

It is not advisable to refuse state support for the establishment and development of institutional infrastructure for the promotion of locally produced products and the implementation of active import-oriented measures. The network and the opportunities for organizing the civil sector are particularly weak in Ukraine today. This is a significant drawback of the institutional and organizational direction of the organizational and economic mechanism of the state structural policy of import substitution. These are associations of manufacturing enterprises, domestic consumer organizations, quality and certification centres for goods and services, social and public marketing services, guilds of socially responsible entities in the SME sector.

The disadvantages are characterized by the constituent organization of the state structural policy of import substitution. This conclusion, in our opinion, is confirmed by the fact that Ukraine lacks a central executive body to regulate structural reforms and import substitution problems. Accordingly, there is no vertical horizontal organizational structure capable of systematically managing structural changes in the spatial aspect.

The main problem is that such an object of regulation as import substitution is at the intersection of domestic production (industrial development, agro-industrial complex) and the interests of other ministries that oversee the economic activity of the real sector of economy, trade, and foreign economic relations. This increases the focus of the representatives of different ministries and agencies. To the greatest extent, this is a question of the Ministry of Industrial Policy of Ukraine and the Ministry of Economic Development and Trade of Ukraine. Therefore, we believe inthat the relevance of creating an interagency structure with the status of the State Agency for Regulation of Import Substitution Problems under the 
Ministry of Economic Development and Trade of Ukraine, which would include representatives of the following ministries: industrial policy, agrarian policy and food, infrastructure, energy and coal. Such an approach would significantly improve the organization of activities to implement an effective state import substitution policy, as well as ensure its proper coordination among related, dependent and determining ministries and departments.

Instead, at present, there is no structural unit within the Ministry of Economic Development and Trade of Ukraine directly assigned to the implementation of import substitution or structural policy tasks. The situation is similar within the Ministry of Industrial Policy of Ukraine.

The regional and subregional components of the organizational direction of the mechanism of state structural policy of import substitution in Ukraine should also be considered insufficient. Thus, it is obvious that the task of regulating the development of the internal market, local production and trade is entrusted to the regional headquarters of the economy or departments of economic development, trade and industry, the head offices of industry and infrastructure development. These structures implement the state policy of economic and social development, price, industrial, regional policy, the state policy in the sphere of trade and services, foreign economic activity in the region. Therefore, these structural subdivisions of regional state administrations have sufficient levers and tools to regulate import substitution problems and structurally balanced development of the internal market, and among the criteria of efficiency of their activity the state of affairs concerning displacement of non-state goods and increase in sales volumes should take an important place.

That is why it is positive that the Regulations on the Department of Economic Development, Trade and Industry of the Lviv Regional State Administration identify the following among the main tasks in the field of regulation of the sphere of trade, services and development of consumer markets: promotion of leading experience in the sphere of increasing import substitution production in the region and coordination facilities in the field of trade, catering, markets for the sale of food and non-food products, restaurant, household and hotel economy exhibiting.

But in our opinion, even formulating this task directly is incorrect, because the experience is not enough to promote. A clearly defined and active state regional policy in this field should be implemented, and this task should be one of the key directions of activity of the main structural economic units of regional and local state authorities in our country.

We consider it positive that much more attention is paid to the implementation of structural and import-substitution policies in the strategic programming documents of the meso- and sub-regional levels. Thus, the first priority direction of the Program of socioeconomic and cultural development of Lviv region for 2014 with macroeconomic forecast for 2015-2016 is "Increasing the competitiveness of the economy and improving the investment climate. Implementation of import substitution policy"- directly related to such tasks (Program of socio-economic and cultural development of Lviv region for 2014 with macroeconomic forecast for 2015-2016, 2013). It is envisaged to promote the development of industrial enterprises of the region, increase the volume of sales of industrial goods on the basis of production of high-tech, competitive products that are in demand in the domestic and foreign markets; expansion of the export base of industry; modernization of existing and commissioning of new production capacities, introduction of innovations, development of new production of import-substituting products at the enterprises. 
A logical continuation of the policy of strengthening the competitiveness of local production and displacement of imported goods is the second priority area of the Program "Structural reforms in strategically important sectors which affect all components of the economy".

But, unfortunately, the ambitious goals of displacing goods imported into the domestic market of the region and improving the position of the local producer did not find continuation in the regional government policy measures planned for 2014. Only in the section "Measures of foreign economic activity" we find "... assistance dissemination in the field of world best practices in the sphere of economic reform, energy saving, development of market economy structures, increase of production of import-substituting products », which is a duplicate of one of the activities of the Department of Economic Development, Trade and Industry of the Lviv Regional State Administration. That is, goals are set, but nothing is done to achieve them. Thus, there are obvious shortcomings in the organization of the work of state structures to implement import-substitution policies at the regional and local levels.

We believe it is appropriate and necessary to create sectors for the implementation of the state structural policy of import substitution with subordination to the relevant agency established at the central level at the head offices of the authorities. Thus, it is possible to build a power vertical, focused on state regulation of one of the most acute problems of socioeconomic development of Ukraine today - high import dependence. We will add that the urgency of this issue is justified by obstacles to the development of the domestic real sector, ensuring high-productivity employment, increasing revenues to budgets (including local) and financing infrastructure development programs, the acquisition of quality domestic goods by the population and improving the system of consumer rights protection.

Ukraine is also characterized by shortcomings in the economic direction of the organizational and economic mechanism of state structural policy of import substitution. In general, this is manifested by insufficiency, and in many cases by the lack of adequate incentives for all economic actors to stimulate the development of domestic production (primarily on the basis of innovation and competitiveness), reducing demand for products not made in Ukraine, improving commodity marketing and strengthening positions of domestic products, especially consumer goods in the domestic consumer market.

At the same time, it must be acknowledged that some positive practices on the use of state economic mechanisms and instruments to stimulate domestic production in strategically important and potentially priority types of economic activity and sectors of the national economy are still available. Thus, in order to develop software and IT technologies in Ukraine in 2013, a preferential taxation of profits (at a rate of 5\%) was introduced and the production and sale of these goods were exempted from VAT, and a zero tax rate on income was introduced for investment projects. in priority types of economic activity. Due to this economic measure, the volume of domestic production of these products and services has increased to $\$ 1.5$ billion. US $\$ 0.4$ billion more than in 2011, the number of employees increased from 25 to 40 thousand people (More than 30,000 Ukrainian IT professionals work for foreign companies, 2019).

Numerous state programs are also aimed at stimulating the development of domestic production and improving its investment and innovation support. To this end, a program of development of investment and innovation activities is being implemented (Resolution "On Approval of the Investment and Innovation Activity Program in Ukraine", 02.02.2011, No. 80), a series of measures of which are aimed at improving attraction of the real investment sector to the domestic enterprises for modernization of production, creation and 
commercialization of the results of innovative activity. Thus, the entities participating in the Program have the opportunity to increase their volume and increase the competitiveness of the domestic manufacturing sector.

The State Target Program for the Development of Investment Activities for 2011-2015 is still being implemented in our country (Order "On approval of the Concept of the State Targeted Economic Program for the Development of Investment Activities for 2011-2015", 29.09.2010, No. 1900-r), while the tasks of the State Targeted Economic Program "Creating Innovative Infrastructure" in Ukraine have been directed to support the innovative activity of domestic entities in the real sector of the economy. 2009-2013 (Decree of Cabinet of Ministers of Ukraine "On approval of the State Targeted Economic Program "Creating Innovative Infrastructure in Ukraine" for 2009-2013", 14.05.2008, No. 106).

But we must admit that the state's activities to introduce economic incentives to develop and strengthen the competitive position of domestic production remains insufficient. There are no targeted financial and investment funds in the country to promote the development of priority areas for economic activities, no effective and real fiscal incentives for innovations are introduced, high technology imports are not sufficiently supported, industrial and territorial clusters are not created, the practice of functioning of technoparks, free economic zones, other elements of the infrastructure of formation and growth of viable production structures is low-performing.

\section{Conclusions}

Regarding the economic stimulation of import substitution, it should be added that in our country there are practically no economic incentives for the retail network and the population aimed at refusing to purchase imported goods. These are fiscal privileges for trade enterprises selling domestic goods (including social ones), grants for marketing firms for the promotion of goods made in Ukraine, in the domestic and foreign markets, and reimbursement by the state of part of the costs of the population for the purchase of locally produced goods, implementation of a number of joint investment and innovation projects of the state and economic entities, the result of which is to strengthen the competitiveness of production and improve positioning domestic products in the domestic market.

\section{References}

Decree of Cabinet of Ministers of Ukraine "On approval of the State Program for the Development of Domestic Production", 12.09.2011, No. 1130. Official Bulletin of Ukraine, 9137. [in Ukrainian].

Decree of Cabinet of Ministers of Ukraine "On approval of the State Targeted Economic Program "Creating Innovative Infrastructure in Ukraine" for 2009-2013", 14.05.2008, No. 106. [in Ukrainian].

Measures are being taken in the Luhansk region to implement the program of import substitution of products. (2019). Government Portal web-site. [Electronic resource]. Retrieved from http://www.kmu.gov.ua/control/en/publish/article?art_id=244897351\&cat_ $i d=244277216$. [in English].

More than 30,000 Ukrainian IT professionals work for foreign companies. (2019). Internet portal of the Educational Portal organization. [Electronic resource]. Retrieved from http://www.osvita.org.ua/news/67762.html?from=news_rss. [in Ukrainian]. 
Order "On approval of the Concept of the State Targeted Economic Program for the Development of Investment Activities for 2011-2015", 29.09.2010, No. 1900-r. [in Ukrainian]. Program of socio-economic and cultural development of Lviv region for 2014 with macroeconomic forecast for 2015-2016. (2013). Web-site of Lviv Regional State Administration. [Electronic resource]. Retrieved from http://loda.gov.ua/oda/upravlinnya/ departament-ekonomichnoho-rozvytku-investytsij-torhivli-ta-promyslovosti/stratehichneplanuvannya/prohramy/1093_prog. [in Ukrainian].

Resolution "On Approval of the Investment and Innovation Activity Program in Ukraine", 02.02.2011, No. 80. [in Ukrainian]. 